\title{
Weak leadership threatens anti-malaria drive
}

Declan Butler, Paris

A major global initiative that aims to halve the world's malaria burden by 2010 will fail unless it is speedily revamped, according to the scheme's first major external evaluation.

A panel chaired by Richard Feachem, director of the Institute for Global Health in California, says that the project, Roll Back Malaria (RBM), needs stronger leadership, a management overhaul and tight focus on a small number of countries where its ideas stand a chance of being put into practice.

The RBM initiative was launched in 1998 by the World Health Organization (WHO), as a partnership with the World Bank and the United Nations, and has since been joined by more than 90 other partners. It aims to direct a comprehensive global effort against the disease, which affects up to 500 million people and kills a million of them each year.

The evaluation was made by seven experts in research, health and economics. It found RBM successful in advocacy and in building a consensus about priorities: after languishing for decades, malaria research and control is high on political and scientific agendas, it says. Funding has almost doubled since 1998 to around $\$ 200$ million in 2002, \$35 million of which is channelled directly through RBM (see News Feature, page 426).

At a summit in April 2000, 44 of Africa's 50 malaria-affected countries pledged to

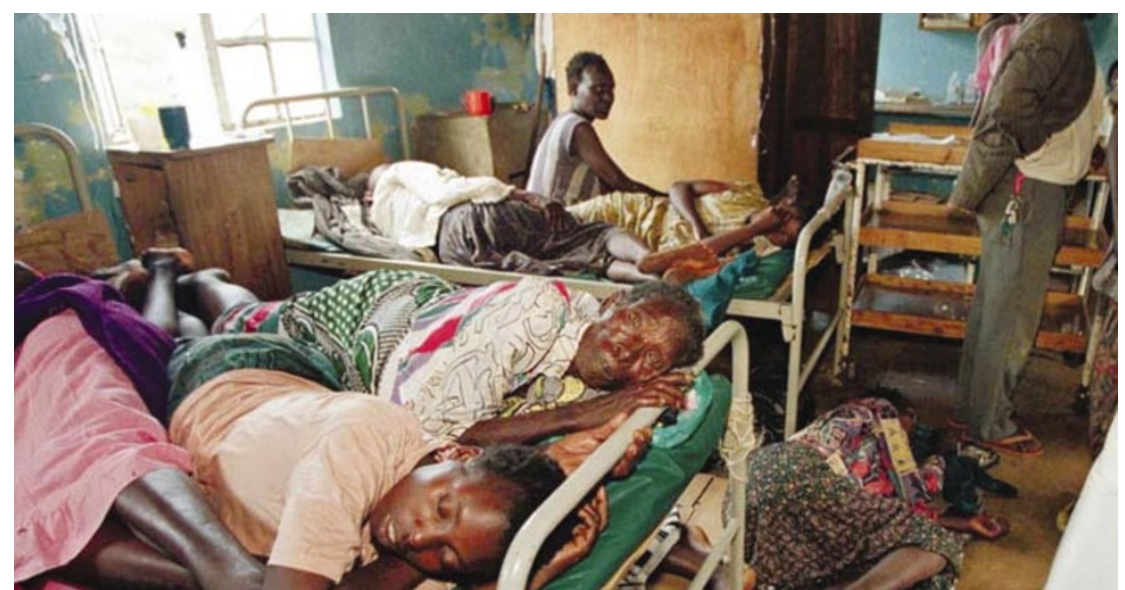

Sick of waiting: slow progress against malaria is failing sufferers such as these patients in Kenya.

support RBM's main goals — particularly that, by $2005,60 \%$ of sufferers get immediate access to treatment. But progress has been sporadic. Only a handful of countries have increased funding and staff to anywhere near the required levels. RBM's own projects, the evaluation says, have too often been implemented in isolation from the broader health policies of recipient nations.

The report adds that RBM and its partners have given inadequate, even conflicting, technical advice to governments. It recommends the creation of technical support networks to collate the best advice, and of an independent governance board to which the RBM secretariat should be accountable. It calls on RBM to reorganize its efforts, focusing on $8-12$ countries that have the political commitment to enable rapid progress.

David Heymann, executive director of WHO's communicable diseases division, says the report agrees with an internal review done last year. "The external evaluation has been very useful," he says. "By the end of this year we expect to have strengthened the partnership based on its recommendations."

\section{Criminal courts 'should take genetics into account'}

\section{David Adam, London}

Stephen Mobley's defence at his trial for killing a pizza-store manager in Jackson, Georgia, was unusual. His lawyers had pointed to a family history of violence, and argued for leniency on the basis that genetic factors contributed to his crime.

Mobley's defence was rejected, and he is now on death row. But in a controversial study published this week - "Genetics and Human Behaviour: The Ethical Context" a leading bioethics group says it may only be a matter of time before courts use genetic evidence to help determine punishments.

The London-based Nuffield Council on Bioethics says that genetic factors should sometimes be cited in mitigation for a crime, just as social factors, such as being a victim of child abuse, already are.

"If it is legitimate for a judge to take upbringing into account then it's legitimate to take genetics into account, providing the data are good enough," says Martin Bobrow, who is head of the department of medical genetics at the University of Cambridge, and deputy chairman of the Nuffield Council.
Some researchers do claim links between a person's genes and antisocial behaviour. A certain form of a gene that breaks down neurotransmitter chemicals has been found to make men more likely to be violent, if they were maltreated as children (Science 297, 851-854; 2002). Before genetics can be used in courts, however, Bobrow says that such results would have to be successfully

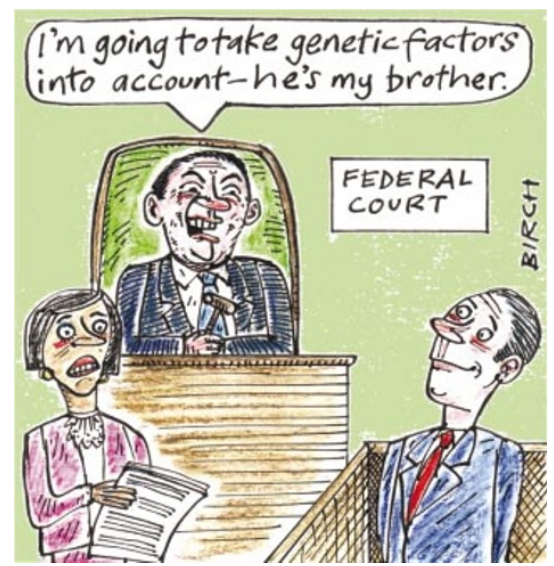

replicated and the magnitude of the effect quantified. For some associations this could be done "within a decade", claims Andrew Wilkie, a medical-genetics researcher at the University of Oxford and a member of the working party that prepared the Nuffield Council report. He adds, however, that very few people would be affected.

But not everyone agrees that genetic influences should be used this way. Sceptics include Craig Venter, the former boss of Maryland-based Celera Genomics. Using genetics as mitigation in courts would be a "dangerous leap", Venter said last week. "I don't see anything in the genetic code that forgives criminal activity," he says.

Some also fear that using genetics in sentencing could lead to the use of gene therapy to try to 'cure' criminals, and the genetic screening of populations for likely offenders. "This poses some fundamental questions for the legal system," says Margaret Somerville, director of the Centre for Medicine, Ethics and Law at McGill University in Montreal, Canada, "because the technology will surely improve." 